DOI 10.37882/2223-2982.2021.12.02

\title{
ОСОБЕННОСТИ ДЕЯТЕЛЬНОСТИ ПРОДОВОЛЬСТВЕННЫХ ОРГАНОВ ТАВРИЧЕСКОЙ ГУБЕРНИИ В ПЕРИОД ГЕРМАНСКОЙ ОККУПАЦИИ В 1918 ГОДУ
}

\section{ON SOME FEATURES OF THE FOOD AUTHORITIES ACTIVITY IN THE TAURIDE PROVINCE IN THE INITIAL PERIOD OF THE CIVIL WAR IN RUSSIA IN 1918}

\section{A. Butovskiy}

Summary: The article looks into the activity features of the Food Authorities of the Tauride province during the German invasion in 1918, based on archival and memoir sources, taking into account the latest research. According to the author, the German occupation of Crimea turned into a key factor in the emerging difficulties of food supply for the population of the peninsula. This applies to both the uncontrolled robbery by the occupiers of this part of Russia, and the geopolitical attitudes of Germany during this period. The artificially created difficulties in the work of the food authorities of the Crimea, in connection with the outbreak of the customs war with Ukraine, quite suited the invaders. The difficulties divided the peoples of Russia and significantly hampered the future restoration of the country's unity. That is why the German command was against any unification of puppet regimes in the occupied territories, even under their own protectorate. However, in the future, taking into account the tendencies for the revival of a united Russia, all clearly coming from the Crimea, the German command made a decision aimed at uniting their puppet regimes (in Ukraine and Crimea) operating in the occupied territory of Russia. Most likely, this was due to the realization that only militant Ukrainians would be able to suppress finally these dangerous for Germany political sentiments in the captured Crimea.

Keywords: Russia, Ukraine, Civil war, German occupation, Taurida province, Customs war.
Бутовский Александр Юрьевич

К.п.н., дочент, м.н.С., ФГБОУ ВО «Тульский государственный педагогический университет им. Л.Н. Толстого»

mrvip76@mail.ru

Аннотация: На основании архивных и мемуарных источников, с учетом новейших исследований, в статье рассматриваются особенности деятельности продовольственных органов Таврической губернии в период германского вторжения в 1918 году. По мнению автора именно германская оккупация Крыма превратилась в ключевой фактор возникших сложностей продовольственного обеспечения населения полуострова. Это касается как бесконтрольного грабежа оккупантами данной части России, так и геополитических установок Германии в указанный период. Искусственно созданные трудности в работе продовольственных органов Крыма, в связи с начавшейся таможенной войной с Украиной, вполне устраивали оккупантов, так как они разделяли народы России и в значительной степени затрудняли будущее восстановление единства страны. Именно поэтому германское командование было против любого объединения марионеточных режимов на оккупированных территориях, даже под своим собственным протекторатом. Однако, в дальнейшем учитывая тенденции на возрождение единой России все отчетливо идущие из Крыма, германским командованием было принято решение, направленное на объединение своих марионеточных режимов (Украины и Крыма), действующих на оккупированной территории России. Вероятнее всего, это было связано с осознанием того, что только воинствующее украинство сможет окончательно подавить эти опасные для Германии политические настроения в захваченном Крыму.

Ключевые слова: Россия, Украина, Гражданская война, Германская оккупация, Таврическая губерния, Таможенная война.

в городе была восстановлена Городская дума (созыва августа 1917 г.). Германские войска не препятствовали деятельности местных органов самоуправления [2, с. 349 - 382], включая работу Советов рабочих депутатов в Севастополе, Феодосии и Ялте, которые функционировали при оккупантах, по меньшей мере, еще два месяца [3, с. 2]. Это хорошо соответствовало военно-политической стратегии Германии, предпринимавшей все «для того, чтобы как можно дальше задержать воссоединение расчлененной России» [25, с. 226]. В первые же дни германской оккупации и.о. городского головы Симферополя А.В. Фосс провел консультации с германским командованием. Представители последнего заявили, что ставят своей ближайшей целью: «установление определенного правопорядка в Крыму для того, чтобы возмож- 
но было в ближайшем будущем наладить правильный товарообмен между Крымом и Германией. Лицо вполне авторитетное, с которым А.В. Фосс беседовал, самым категоричным образом заявил, что никакого отношения к Крыму Украина не имеет, и иметь не будет. Крым, по видимому, рассматривается германцами как вполне самостоятельная страна, причем германскому командованию безразлично, какой именно государственный строй будет установлен в Крыму, «ибо не нам здесь жить, а вам», как было сказано А.В. Фоссу. В частности, германцы не намерены посягать ни на наш суд, ни на наши законы...» $[40$, с. 1$]$.

8 (21) апреля 1918 г. Руководители Таврического Губернского комиссариата Совета народных представителей, П.И. Бианки, В.П. Поливанов заявили о том, что они возобновляют деятельность и приступают к исполнению своих обязанностей $[45$, с. 1]. Для согласования работы в губернских учреждениях было создано «Особое совещание при губернском комиссаре» из представителей государственных и общественных деятелей, которое начало работать с 27 апреля. С докладом о продовольственных перспективах выступил председатель ГПУ А.А. Стевен. По докладу совещание решило, что губернская продовольственная управа должна быть сохранена в интересах населения [38, с. 3].

Благодаря сотрудникам последней удалось сохранить мануфактуру стоимостью до 20 миллионов руб., и до 10 миллионов руб. наличностью, которые надеялись использовать для обмена на продовольствие [11, с. 3]. Данными сотрудниками продовольственных органов Крыма также была проведена огромная работа по обеспечению Крыма хлебом. Уже с вступлением германских войск в Северную Таврию управой дано распоряжение о доставке в Евпаторию и Керчь до ста тысяч пудов разного хлеба из Скадовска и Хорл. Однако вслед за наступающими германскими войсками шли войска и власти самопровозглашенной Украины, претендующие не только на северные уезды, но и на Крым. В этой связи противоречие между данными силами стали проявляться, в том числе и в вопросах продовольственной политики.

Так, одной из наиболее актуальных проблем Таврической губернии этого времени являлась хлебная монополия. Необходимость сохранения хлебной монополии в Крыму было признано германскими властями. Однако такой монополии пожелало и население северных уездов, включенных в состав Украины [44, с. 2].

В Керчь было доставлено только около 130000 пудов хлеба, в то время как для населения Крыма по оценке Губернской продовольственной управы требовалось, по крайней мере, не меньше 400 тысяч пудов хлеба. А.А. Стевен в результате переговоров с германцами договорился о поставке для Крыма из портов Цареводарский и Ногайска, еще до 300 тысяч пудов пшеницы. Пшеница вновь доставлялась, в связи активным противодействием марионеточного украинского режима, кружным путем в Керчь, а оттуда после перемола уже в Ялту и Севастополь, или железной дорогой в Симферополь. Кроме того, управа оформила запрос командованию разрешить доставить им еще 100 тыс. пудов ячменя и сена со станций Мелитопольского уезда [29, с. 2]. Германское командование так же активно приняло участие в снабжении населения сахаром. В начале мая оно закупило для населения Симферополя 10 вагонов сахара [32, с. 2]. Решалась проблема и с топливом. Заготовкой дров для всей Таврической губернии, как и раньше [21, с. 4], была занята Геническая продовольственная управа, хотя непосредственно сам Геническ, теперь отходил под юрисдикцию самопровозглашенной Украины. Такое внимание германского командования к доставке продовольствия на оккупированные территории России, разумеется, было связано не заботой о мирном населении, а, в первую очередь, необходимостью обеспечить нормальным питанием свои войска, расквартированные в захваченных городах и поселках.

Тем не менее, роль продовольственных органов местного самоуправления, в решении вопросов, связанных с поставками продовольствия для мирного населения, была огромна. В этом контексте необходимо рассматривать и проведение реорганизации управления в продовольственных органах, включая «чистку рядов». Например, в Симферопольской городской продовольственной управе была произведена реорганизация штатов отделов продовольствия и снабжения - старый личный состав бухгалтерии уволен и набран новый. Всего в управе на службе осталось 8 сотрудников, остальные уволены. Начался набор новых работников [4, с. 1].

Разумеется, отношения с германским командованием органов местного самоуправления, были в достаточной степени сложными и противоречивыми. С одной стороны принудительной выемки хлеба не производилось. С другой, немцы постоянно требовали снижения цен на продукты, чтобы иметь возможность их скупки. Поэтому борьба велась буквально за каждую копейку. Об этом красноречиво говорят страницы газеты «Крым». Регулярно публиковались таксы на продукты первой необходимости. Свободная торговля была разрешена [41, с. 2]. В результате усилиями Таврической городской продовольственной управы их до конца оккупации удавалось держать несколько завышенными, а население снабжать по карточной системы.

8 мая (21) мая для урегулирования вопросов, связанных с северными уездами губернии и получения оттуда продовольствия в Крыму Председатель Таврической ГПУ А.А. Стевен и член управы Н.Г. Гусев выехали в Киев для переговоров с марионеточным украинским режи- 
мом [30, с. 2]. Они проводились, с так называемым «министром» Ю.Ю. Соколовським [11, с. 3]. В ходе поездки А.А. Стевен был также представлен и «ясновельможному пану гетману» $[27$, с. 2].

Не удивительно, что конструктивного диалога не получилось, ведь люди, с которыми общались крымские представители, исключительно руководствовались провокационным решением, принятым 3(16) мая, о присоединении Крыма к самопровозглашенной Украине [36, с. 229 - 230]. По словам П.П. Скоропадского только после такого акта, полуостров был бы обеспечен «продуктами первой необходимости, как соль, табак, вино и фрукты» [13, с. 146]. А.А. Стевену предлагалось реорганизовать Городскую продовольственную управу в Таврическую контору государственного хлебного бюро Украинской державы, ссылаясь на то, что якобы по договору с немцами, Крым передается Украине [11, с. 3]. 13 (26) мая крымские представители вернулись в Симферополь [10, с. 2]. Результаты переговоров были доложены на заседании 52-го Таврического губернского земского собрания.

Вызывает интерес, что в данной непростой ситуации, с согласия германского командования, к власти в Крыму приходит военно-политическая группировка во главе с генерал-лейтенантом М.А. Сулькевичем. Не вызывает сомнений, что создание на территории южных губерний России, в условиях германской оккупации, двух марионеточных режимов П.П. Скоропадского и М.А. Сулькевича, выглядело совсем не случайным. По-видимому, это было необходимо, как представляется, для успешного управления территориями с «туземным» населением, а также для беспрепятственной выкачки с захваченных российских территорий имущества и продовольствия [18, с. 379]. Из одного только Севастополя, сразу же после появления в городе, германцы вывезли полмиллиона консервов, 900 пудов чая, запас сахара на 4 месяца. Начался безудержный грабеж крымских предприятий, морских портов и даже ханского и царских дворцов. Пострадал даже парадный кабинет Николая II [18, с. 396 - 397]. Ежедневно из Крыма в Германию отправлялись загруженные ворованным добром поезда. Не отставали от своего начальства и простые солдаты, которые «ежедневно отправляли родным маленькие посылочки с хлебом и другими продуктами края» [6, с. 2]. В дальнейшем грабеж был оформлен германцами через создание, так называемого «германо-австровенгерского экономического центра», без которого никто на полуострове не мог продать ни фунта пищевых продуктов, причем по ценам на 50 - 100\% ниже рыночных [34, с. 24]. По всему Крыму, помимо установления твердых цен, германским командованием был запрещен ввоз, вывоз и передвижение продовольственных грузов. Одновременно с данными запретами, массовый характер стали приобретать их неизбежные спутники: реквизиции, конфискации и секвестрации [34, с. 25].
Тем не менее, существенные коррективы в этот процесс внесли северные соседи. Угроза Крыму со стороны самопровозглашенной Украины, оказалась не надуманной и вскоре вылилась в так называемую таможенную войну. 6(19).06. 1918 г. Украина прекратила почтовое сообщение морем, а 23.06 (6.07.) телеграфное сообщение с Крымом [8, с. с. 2]. В тот же день в Феодосию пришел транспорт из 23 каботажных судов украинских торговцев из Бердянска для закупки фруктов. Однако в ходе погрузки выяснилось, что упаковочной тары явно не хватает, как и приспособлений для сушки плодов, которые по этой причине можно продать только в свежем виде. Цены на фрукты резко упали [42, с. 4].

В Крыму в это время 12(25) июня, была опубликована Декларация Крымского Краевого правительства, под названием «Правительственное сообщение. Об образовании Крымского Краевого Правительства и декларация его» [37, с. 1-7]. Этот документ не так давно был опубликован и прокомментирован [15, с. 213 - 218]. Интересующие нас продовольственные органы реорганизовались в учреждения Крымского Края, а старые Губернские подлежали ликвидации. На должность и.д. председателя Крымской краевой продовольственной управы был назначен Теодор Адамович Левандовский [24], служащий Таврической губернской управы с 1904 г. И ближайший помощник А.А. Стевена по Губернской продовольственной управе. Последний, продолжал занимать свою прежнюю должность вплоть до полной ликвидации дел.

24 июня (7 июля) 1918 г. самопровозглашенный марионеточный украинский режим пошел на радикальные меры, введя полный запрет на ввоз и вывоз продовольственных товаров в Крым [12, с. 187 - 188]. то есть, фактически объявив таможенную войну населению Крыма. Даже в пограничных пунктах, например на Перекопе, представители украинского режима потребовали от местных жителей продать зерно не на полуострове, а на подконтрольной им территории [18, с. 380]. Главной целью таких действий было «путем категорического воспрещения ввоза, каких бы то ни было продуктов», заставить крымскую власть капитулировать [22]. Это вынудило Краевой Совет Министров опубликовать сообщение о сохранении твердых цен на хлеб, а также о переформировании Таврической губернской продовольственной управы в Краевую, обслуживающую только Крым [7, с. 3]. 23 июля (5 августа) украинское правительство ввело запрет на въезд и выезд из Крыма [9]. В.С. Налбандов, по этому поводу писал: «...С 25 июня по 9 сентября [н. ст.] мы не получили ни одного требования, предложения или запроса Украины - с нами просто не разговаривали и всеми мерами добивались лишь одного - покорения Крыма... Требовалось одно - капитуляции без условий» $[17$, с. 109]. В этих условиях Германия заняла своеобразную позицию, явно не вмешиваясь в разгорающийся конфликт и даже предпринимая попытки, точнее опре- 
делить границы между двумя своими марионеточными режимами [19, с. 42 - 44]. Ситуация в Севастополе, поставленном на грань голода и в Симферополе, где были введены карточки на хлеб [18, с. 381], вероятно вполне устраивала оккупантов, так как разделяла народы России и затрудняла впоследствии восстановлению единства страны. Отсюда, германское командование было против любого объединения марионеточных режимов на оккупированных территориях, даже под их собственным протекторатом. Это отчетливо проявилось 2 - 3 июля на имперской конференции под председательством кайзера [43, с. 238 - 239].

Любопытно, но в условиях таможенной войны активизировалась деятельность негосударственных кредитных и кооперативных обществ. Данные организации с небольшим обозначенным уставным капиталом, стали играть огромную роль в снабжении населения крымского края товарами первой необходимости, преимущественно продовольствием, мануфактурой и горючесмазочными материалами. Таким образом, во многом именно противостояние с самопровозглашенной Украиной привело к консолидации и росту кооперативного движения. В частности 29 июня (12 июля) Симферопольским Окружным Судом был зарегистрирован Крымский союз потребительских обществ (Крым СПО), объединивший 4 потребительских общества (2 в городе и 2 в уезде) снабжаемых кредитом 1-м Симферопольским обществом потребителей. Паевой капитал - 10 тыс. руб. 23 июля (5 августа) состоялось его учредительное собрание. Первым председателем правления был приглашен А.А. Стевен, Членами правления И.И. Штван (бывш. Председатель Президиума СНП, с.-р.), К.И. Шишов, Д.Д. Рихтер, позднее Г.О. Диканский (член Учредительного собрания, к.д.) и др. Имея в начале своей деятельности около 100 тыс. руб. капитала уже через полтора года Крым СПО смог приобрести в Симферополе дом за 3,5 млн. При этом союз фактически объединил все потребительские общества Крыма, за исключением Феодосийского и Севастопольского регионов, которые имели свои традиционно мощные кооперативные организации [28, с. 18]. Законодательно такое кооперативное движение, регулировалось Императорским, Временным и Крымскими Краевыми правительствами [28, с. $121 ; 39$, с. $117 ; 35$, с. $10-22 ; 5$, c. $34-39$ ].

Таким образом, раздавить Крым в блокаде самопровозглашенному украинскому режиму не получилось. Однако вскоре отношение к данной проблеме германцев, резко изменилось. Теперь оккупанты стали допускать возможность объединения созданной ими Украины с Крымом на правах автономии полуострова [18, с. 389 392]. Вероятнее всего, на данном этапе германское командование решило, что, в этом случае, воинствующее украинство сможет окончательно подавить тенденции на возрождение единой России, все отчетливо набира- ющие силу в Крыму. Тем не менее, крымчане, несмотря на германскую оккупацию, категорически отказались соединяться с «частью бывшей России, в особенности с такой, которая стоит против объединения России» [23]. В ответ марионеточный украинский режим вновь возобновил таможенную войну, причем если раньше можно было, еще как-то провести продукты для собственного потребления, то теперь стали отбирать практически все. Одновременно, от крымской же оппозиции, последовало серьезное обвинение правительства М.А. Сулькевича, которое якобы не успело воспользоваться временем переговоров и не сделало своевременных запасов продовольствия на полуострове. В итоге над Крымом нависла реальная угроза голода [23]. В этой связи, не вызывает сомнений, что указанные действия марионеточного украинского режима, не являлись самостоятельными решениями лиц, его представлявших. За такими действиями явно стояли далеко идущие планы и конкретные приказы германского командования. Косвенно, на это указывает, хотя бы донесение 52-му германскому корпусу, дислоцированному в Крыму, об изменениях тактики в изменившихся условиях, которые выразились в отказе в поддержке М.А. Сулькевича и необходимости формирования нового правительства на полуострове [43, с. 252 - 253]. Более того, на фоне подъема оппозиционного движения против М.А. Сулькевича, 3 ноября 1918 года генерал Кош официально заявил об отказе от поддержки опального генерала [18, с. 401 - 402]. 25 - 28 октября (7 - 10) ноября депутаты съезда гласных крымских уездов Таврического губернского земского собрания с участием представителей от городских самоуправлений, уездных и волостных земств и членов Всероссийского учредительного собрания потребовали смещения кабинета М.А. Сулькевича и создание ответственного министерства во главе С. С. Крымом [16].

В конечном итоге М.А. Сулькевич был вынужден отказаться от власти в пользу С.С. Крыма, что по понятным причинам совпало с принятым 15 ноября властями Украины постановлением о прекращении таможенной войны с Крымом, ввиду предполагавшегося объединения бывших частей России на борьбу с большевиками [33, с. $782,787]$. Тем не менее, данный план сорвался, так как в это время германское командование уже приступило к выводу войск с территории России, в связи с революционными событиями в Германии.

Таким образом, германская оккупация Крыма являлась ключевым фактором возникших сложностей продовольственного обеспечения населения полуострова. Однако дело здесь было не только в стремлении бесконтрольного грабежа оккупантами этой части России. Представляется что в вопросах продовольствия, не менее важную роль сыграли геополитические установки Германии. Искусственно созданные трудности в работе продовольственных органов Крыма, в связи с начавшей- 
ся таможенной войной с Украиной, вполне устраивали оккупантов, так как они разделяли народы России и в значительной степени затрудняли будущее восстановление единства страны. Именно поэтому германское командование было против любого объединения марионеточных режимов на оккупированных территориях, даже под своим собственным протекторатом. Однако, в дальнейшем учитывая тенденции на возрождение единой России, все отчетливо идущие из Крыма, германским командованием было принято решение, направленное на объединение своих марионеточных режимов
(Украины и Крыма), действующих на оккупированной территории России. Вероятнее всего, это было связано с осознанием того, что только воинствующее украинство сможет окончательно подавить эти опасные для Германии политические настроения в захваченном Крыму. Все это до крайней степени обострило работу местных продовольственных органов и стало одной из главных причин падения правительства М.А. Сулькевича на полуострове. Только вывод германских войск с территории России смог предотвратить такое негативное развитие событий.

ЛИТЕРАТУРА

1. Бутовский А.Ю. К вопросу о крымско-украинской таможенной войне в 1918 году // Историческая и социально-образовательная мысль. 2017. Т. 9. № 3/2. C. $33-41$.

2. Бутовский А.Ю., Бобков А.А. 0 некоторых вопросах захвата германскими войсками Крыма в апреле 1918 г. // История и археология Крыма. 2020. Вып. XII. C. $349-382$.

3. В Крыму // Новая Жизнь. Общественно-литературная социал-демократическая газета. Петроградское издание / отв. ред. В. Десницкий (Строев), Издатель А.Н. Тихонов. Пг., 1918. № 93 (308). С. 2.

4. В Продовольственной Управе // Крым. Ежедневная общественно-политическая и литературная газета. 1918. №8 (воскресенье 26 мая). С.1.

5. Велигодский Д.В. Правовая база развития и деятельности потребительской кооперации Крыма во второй половине XIX - начале XX вв. // Ученые записки Таврического национального университета имени В. И. Вернадского. 2007. Т. 20 (59). № 2. С. 34-39.

6. Винавер М.М. Наше правительство: (крымские воспоминания 1918-1919 гг.). Издание посмертное. Париж, 1928. 240 с.

7. Відродження. 1918. №83. (середа 10 липня (27 червня)). С. 1 - 4.

8. Вісти з Крыму. (УТА) 6.07.1918 г. // Відродження: щоденна безпартійна демократична газета. 1918. №.82. (вівторок 9 липня (26 червня). С. 2.

9. ГАРК Ф. Р-999. Оп. 2. Д. 399. Л.15.

10. Городская хроника // Крым. Ежедневная общественно-политическая и литературная газета. 1918. №9 (среда 29 мая). С. 2.

11. Делегація від Таврії // Нова Рада: щоденна політична, економічна і літературна газета. Київ: друк. Акц. Т.-ва «Петро Барський у Київі», 1918. №75 (неділя 14 (1) травня). С. 3.

12. Діденко І. О. Боротьба за приєднання Криму як прояв соборницької політики Української Держави (1918 р.) // Соборність як чинник українського державотворення (до 90-річчя Акту злуки) Всеукраїнська наукова конференція. Київ, 21 січня 2009 р. Київ: Поліграф. НАН України, 2009. С.183 - 196.

13. Дорошенко Д. І. Історія Украины Історія України 1917-1923 рр. в 2 т.: Т. 2. Українська Гетьманська Держава 1918 р. / Дмитро Дорошенко; (упоряд., авт. передм. та комент. К. Ю. Галушко). Київ: Темпора, 2002.514 с.

14. Драбкина С.М. Крах продовольственной политики германских империалистов на Украине (февраль - июль 1918 гг.) // Исторические записки. 1949. Т. 28. C. $69-110$.

15. Ефимов С.А. Административно-территориальные преобразования Крыма и опыты Крымской государственности в годы Первой мировой войны // Первая мировая война и Крым: сб. ст. / под ред А.В. Мальгина. Симферополь: 000 «Антиква», 2015. С. 194-218.

16. Журналы заседаний съезда гласных крымских уездов Таврического губернского земского собрания с участием представителей от городских самоуправлений, уездных и волостных земств и членов Всероссийского учредительного собрания 7-10 ноября 1918г. [6.м.] 1918. 18 с.

17. Записки В.С. Налбандова // Красный Архив. Исторический журнал / Под. ред. В.В. Адоратского, В.В. Максакова, М.Н. Покровского, В.П. Полонского, В.М. Фриче. М.; Л.: Госиздат, 1928. Т. 3(22). С. $98-114$.

18. Зарубин А.Г., Зарубин В.Г. Без победителей. Из истории Гражданской войны в Крыму. Симферополь: АнтиквА, 2008. 728 с.

19. Зарубин В.Г. К вопросу о территориальном споре между Крымом и Украиной (1918г.) // Проблемы политической истории Крыма: итоги и перспективы. Симферополь, 1996. С. $42-44$.

20. Зарубин В.Г. Проект «Украина». Крым в годы смуты (1917 - 1921 гг.). Харьков: Фолио, 2013. 379 с.

21. Известия Севастопольского Совета Военных и Рабочих депутатов. 1917. №93 (четверг 8 сентября). С. 4.

22. Крымский вестник. 1918. 28 июня.

23. Крымский вестник. 1918. 22 октября.

24. Крымское Краевое Министерство Земледелия Крымского Краевого правительства за 1918-1919 гг. / ГАРК. Ф. Р-2269. Оп. 2. Крымское Краевое Министерства Земледелия. Д. 2. По вопросам об учреждении Министерства, о выработке штатов, о выдаче дополнительных вознаграждений и проч. 2 июня 1918 г. Л. 85.

25. Линев К.К., Шарапа В.Ф. Крымское краевое правительство С. Сулькевича // Материалы по археологии, истории и этнографии Таврии. Симферополь, 1996. Вып. V. С. $226-234$. 
26. Мальгин А.В. Внешняя политика Крымского краевого правительства генерала Сулькевича // Крымский музей. Симферополь. 1994. № 1. С. 56 - 66.

27. Мануфактурный голод в Симферополе // Крымский Вестник. Газета политической и общественной жизни. 1918. №47 (9328) (вторник, 2 июля (19 июня)). C.2.

28. Николаенко Н.В. Крымская кооперация. Симферополь: Таврия, 1992. 121 с.

29. 0 снабжении Крыма хлебом // Южные ведомости. Ежедневная газета Таврического Союза журналистов и Литераторов. 1918. № 4(16) (воскресенье 12 мая). С. 2.

30. Отъезд председателя губ. продовольственной управы // Южные ведомости. Ежедневная газета Таврического Союза журналистов и Литераторов.1918. № 1(13) (четверг 9 мая). С. 2.

31. Правительственное сообщение М.А. Сулькевича 15 ноября 1918 года / ГАРК.Ф.Р-999. Оп.1. Д.163. Л. 85 - 86.

32. Продовольствие // Крым. Ежедневная общественно-политическая и литературная газета. 1918. №3 (среда 15 мая). С. 2.

33. Протокол допроса бывшего министра юстиции В.Е. Рейнбота. 16 января 1919 г. // Гетман П.П. Скоропадский. Украина на переломе. 1918 год: Сборник документов / Отв. ред. и отв. сост. О. К. Иванцова. М.: Политическая энциклопедия Росспэн., 2014. 1087 с.

34. Розеноер Е.Н. Германская оккупация Крыма. Что она дала краю и что взяла. Феодосия: тип. А.Е. Цвибака, 1919. 40 с.

35. Сборник постановлений Временного правительства по кооперации. 0 кооперативных товариществах и их союзах от 20 марта 1917 г. 0 регистрации товариществ, обществ и союзов от 21 июня 1917 г. 0 съездах представителей кооперативных учреждений от 1 авг. 1917 г. М.: Сов. всерос. Кооп. съездов, 1917. 29 C.

36. Сергійчук В. Етнічні межі і державний кордон України. Вид. 3-є, доповнене. К.: ПП Сергійчук М. І., 2008. 560 с.

37. Собрание узаконений и распоряжений Крымского Краевого правительства. Симферополь. Тип. МВД., 1918. №1. С. 1-16//Фонды Библиотеки Крымского Республиканского Краеведческого Музея Д. 708 11978/364 осн.

38. Совещание при губернском комиссариате // Наш голос. Орган Центрального Бюро Профессиональных Союзов г. Симферополя. 1918. № 3 (среда 1 мая (18 апреля)). С. 3.

39. Стамболин В.А. Крымпотребсоюз: его история и люди. Симферополь: Таврида, 2005. 327 с.

40. Судьба Крыма // Наш голос. Орган Центрального Бюро Проф. Союзов г. Симферополя. 1918. №2 (вторник 30(17) апреля). С. 1.

41. Такса на предметы первой необходимости // Крым. Ежедневная общественно-политическая и литературная газета. 1918. №11 (воскресенье 2 июня). С. 2.

42. Транспорт українських кораблів (УТА) // Відродження: щоденна безпартійна демократична газета. 1918. № 83 (середа 10 липня (27 червня)). С. 4.

43. Федюшин 0.С. Украинская революция. 1917-1918. М.: Центрполиграф, 2007. 333 с.

44. Хлебная монополия // Крым. Ежедневная общественно-политическая и литературная газета. 1918. №3 (среда 15 мая). С. 2.

45. Хроника // Наш голос. Орган Центрального Бюро Проф. Союзов г. Симферополя. 1918. №3 (среда 1 мая (18 апреля)). С. 1.

(с Бутовский Александр Юрьевич (mrvip76@mail.ru).

Журнал «Современная наука: актуальные проблемы теории и практики»

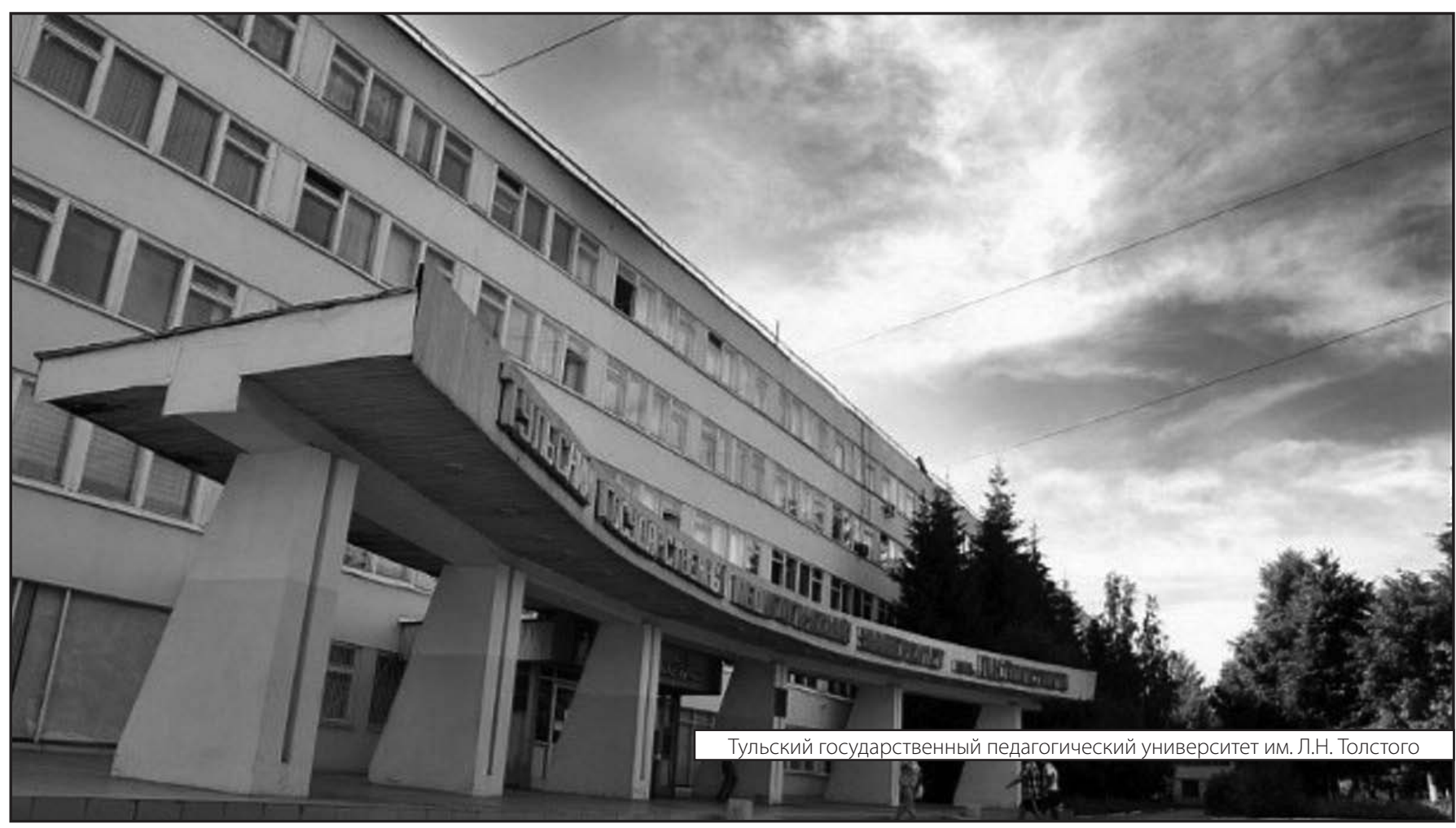

